\title{
GENDERING AND SPATIALIZING THE NEW URBAN SPACE: A STUDY ON WORKING WOMEN IN THE CITY OF DHAKA, BANGLADESH
}

\author{
Wasifa Tasnim Shamma*
}

\begin{abstract}
This paper will explain the gendering and spatializing of Dhaka city that unearths the interaction between the new urban public space and women's spatial practices. These women are working in different shopping malls, fashion houses and beauty parlours of the city which was impossible for them few decades ago. This study has replicated the theoretical position of Lefebvre (1991) on production of space and Harvey (1989) on spatial practices. Tonkiss's (2005) 'Geography of gender' has been used to describe the gendering and spatializing the new urban space of Dhaka. In short, the study has collected data using survey method and supplemented the quantitative findings with qualitative data by some unique and informative case studies. It reveals that the new urban space of Dhaka has been produced by increasing consumerism and the rise of private service sectors where huge numbers of women are working nowadays. It further exposes that the empowerment of women and simultaneously the unemployment of men is contributing to unleashing traditional patriarchy from being confined to domestic spheres. Men are now harassing women in public place more than ever before to hold up their masculinity symbolically. Consequently, women's free movement in the public space is being restricted by their perception and experience of harassment by certain male population of the city and by women's protective negotiation of the space. The paper thus argues that harassment against women in the public space in Dhaka has recently been connected to increasing participation of women in private service sectors during the recent neoliberal transformations.
\end{abstract}

Keywords: new urban space, spatial practices, gender, new private service sector

\section{Introduction}

Urbanization has made us to rethink the concept of city because of global economic redesign. Contemporary cities are characterized by an economic

\footnotetext{
* Wasifa Tasnim Shamma is Lecturer, Department of Sociology, University of Dhaka. Email: tasnimwasifa.du@gmail.com
} 
reshuffling where service sector predominates over manufacturing (Friedmann \& Wolff, 2017). Therefore, now people can think of a new urban life, living and newer livelihood options with the new economy of the city. Most importantly, overgrowing service-based economy, increasing working women in this sector and ever-increasing consumerism have remarkably featured the new space of the city (Thorbek, 1988). Ortiz, Garcia-Ramon, and Prats (2004) also approved that urban renewal has produced a new public space with new services and business such as cafes, restaurants, fashion shops etc. Recently, Reichenbach (2015) explored the new urban space and urban development occupied by luxurious shopping malls, hotels, parks, manmade islands, services, tourism, real state etc. And, with this urban development young women's public visibility in the city with their work, study, business, shopping etc. is found even more. But unfortunately, increasing presence of male strangers in certain areas of the city threatens women's visibility in urban public places. Therefore, economic, political, and social changes have altered the character of the city as friendly for women and questioned severely the safety of women in public space in recent times (Khan, 2013).

The city of Dhaka is the major and the most urbanized area of Bangladesh. It has become the core of finance, culture, and business in the country. For the country, it has been a serious concern since independence to incorporate women into activities of economic development. Luckily, women's position has been changing since 1980 s by a global economic restructuring. In the recent decades huge numbers of women are migrating to the city of Dhaka for employment (ActionAid, 2014). The present study has focused on particularly three private service sectors- shopping malls, fashion houses and beauty parlours where particularly young, less educated, and indigenous women are getting more employment opportunities and thereby getting empowered in the city of Dhaka. But regrettably the men of the city are recapturing their masculinity against women's empowerment by harassing women in public space since they cannot inflict violence against women in domestic place as before. These men are often unemployed and occupy the public space of the city and harass women at some places at some unfriendly times. Phadke (2013) also found out that urban public space is unsafe for women majorly for the unfriendly behaviour of lower-class men, often unemployed and migrant who prevent women from venturing out the city. Consequently, women's freedom and freer movement has been severely restricted by their experience and perception of harassment in the public places of 
the city. Valentine (1989) argued that women's perceived vulnerability at perceived places at particular times shapes their use of space (Valentine, 1989).

Recently, Walsh (2015) supported that women's behaviour, movement and autonomy is constrained for their fear of crime in their daily lives outside their home. Again, Rahbari and Sharepour (2015) reinforced that social practices of women in urban public spaces are hindered for the domination of men at certain places at certain dangerous times. And women use defensive strategies to protect themselves from unfavourable incidents. Soenen (2007) therefore, argued that public space is socially produced based on gender, social characteristics, and background of people. In this sense urban space has been spatialized and gendered (Tonkiss, 2005). Reichenbach (2015) insisted that context and timing determine gendered nature of particular places. Division of space based on gender is the geography of gender which restricts women's use of urban space or spatial practices by their fear and experience of harassment as well as adoption of protective strategies in the public place of the city. This paper has explored how contemporary Dhaka has become a space of freedom and danger concurrently for women appearing in the public space of the city. Spatial practices of women incorporate their mental mapping and experiencing of gender harassment and violence while remaining in the urban public places. Also, these practices integrate women's negotiation of space to remain safe in the city.

\section{Data and Methods}

Women working in different beauty parlours, fashion houses and shopping malls have been selected for the study to incorporate their experience and perception of fear while using urban public space. The study surveyed forty-six women from beauty parlours, forty-three from fashion houses and forty-one from shopping malls of Dhaka to draw a cross sectional image of the new urban space and spatial practices of women. Further, some unique and informative cases of female service workers were brought together to supplement the findings of the quantitative data. New urban space was sketched based on significant changes observed by female service workers of the city. The design of new space integrated the fact of women's empowerment, its impact on traditional masculinity and gendered use of public space. Women's movement in public space, their mental mapping of fear, experiences of harassment, adoption of protective behaviours to remain safe in public places illustrate their spatial practices. 
From the city of Dhaka, Dhanmondi, Shahbug and Nilkhet were chosen from South City Corporation and Mirpur-1, Mirpur-10, and Banani from North City Corporation. These areas have been selected for the study as they are the heart of enormous shopping malls, beauty parlours, fashion houses where many women are working for their survival. It is also purposeful to select these areas for the rise of consumer class rushing to avail the services of these new private service sectors. As the study required informative, in-depth, and in-detail data, 'face to face' mode was selected for administering the questionnaire to the sample. After collecting data from the respondents, the quantitative data were analysed and interpreted through statistical software (SPSS). The exclusive and informative stories of the perception and lived experiences of the respondents were described in the form of narrative analysis.

\section{Theorizing Space, Gender and City}

The growth of service economy majorly predominated by consumer services has rebuilt the urban space and resulted in the commodification of urban life. Harvey (2009) implied that the city and the quality of urban life have been commodified. Urban living is now accompanied by shopping malls, multiplexes, cafes, departmental stores, fashion industry, culture, and knowledge-based industries. Zukin called it 'Pacification by cappuccino' (Koch \& Latham, 2013). This urban renewal has put the female body in space by employing them in consumer servicing activities (new private service sectors) and simultaneously making them vulnerable to urban insecurities. At the same time, Harvey (2009) observed threatening of urban identity, citizenship and belonging as well as individual security in the face of criminal activity promoted by a neoliberal ethic. But he particularly focused on the fortification of the city and creative dispossession apart from a right to a gendered city. The city and city space have also been gendered because of material spatial practices, representation of space and psychological inventions. For Harvey (1989), the first dimension of 'Grid of spatial practices' is material spatial practices characterized by Lefebvre (1991) as experienced. These refer to physical and material flows of interactions that take place in and across space. The second one lies in the representation of space characterized as perceived. It includes all the symbols and significations, set of laws and understanding. It let the material practices to be accomplished with regards to everyday common-sense. The third dimension of spatial practices 
incorporates psychological inventions like codes, symbols, spatial discourse, utopian plans, imaginary settings, figurative spaces, built environments etc.

Harvey (1989) pointed out another four aspects of spatial practices to capture the condition of postmodernity. Firstly, accessibility and distanciation measures the extent to which the friction of space has been conquered to have room for social interactions. Secondly, the appropriation of space denotes the process by which particular objects such as houses, factories, streets etc. and activities such as land use and persons, classes, and social groupings such as gangs appropriating the corner of the street. Thirdly, the domination of space refers to how the organization and production of space are dominated by individuals and powerful groups who appropriate the space. Finally, the production of space is defined by the process of the production of new systems such as transport, communication, technology etc. that facilitate the accessibility and distanciation. So, it can be inferred that appropriation of space by powerful group of people results in the domination of space by that powerful group. The production of space again contributes to overcome the friction of space. Harvey (1989) commented,

These four dimensions to spatial practices are not independent of each other. The friction of distance is implicit in any understanding of the domination and appropriation of space, while the persistent appropriation of space by a particular group (say the gang that hangs out on the street corner) amounts to a de facto domination of that space. The production of space, in so far as it reduces the friction of distance alters distanciation and their conditions of appropriation and domination. (Harvey, 1989, p. 222)

The body exists in space and submits to authority. Capitalist concern no longer does anything with the product to be sold but more with money, sex, and power. Harvey (1989) liberated space because of the spatialization of social practices instead of being localized. He attached social meanings to spaces and time as different groups put different meanings to space and time by using them. Spatial practices are derived from capitalism and take different meanings in accordance with different social relations of class, gender, community, ethnicity, or race. Inspired by Lefebvre (1991), Harvey (1989) proposed that spaces are occupied by objects (e.g., hearth, home, open places, street, squares, markets etc.), activities (use of spaces), individuals, classes, gender. The organization and production of space is dominated by individuals or powerful groups which represents spaces as spaces of fear or spaces of repression (Harvey, 1989). Particularly, the domination of male violence shapes women's uses of space by their fear of and subjugation in urban space. This feared and subjugated 
space is subsequently producing spatial rules which are commanding female bodies, free will and movement. Lefebvre cited in Harvey (1989) purported that space reproduces spatial code that restricts activity in space, commands bodies, prescribes and proscribes gestures, routes, and distances to be covered. Lefebvre captures our attention to the critical phase of the city 'The harbinger of the certain globalization of the urban' (Harvey, 1989). This critical phase has been brought into light by exemplifying it with the pros and cons of streets. For Levebvre (1991), the highly trafficked and busy street provides security against criminal violence such as theft, rape, or assault. So, vanishing of street intensifies criminality. Movement in the street has thus become not only mandatory but also repressed (Harvey, 1989).

It is the endeavour of Tonkiss (2005) to theorize gender and space in the city. She explored how the perception and the use of urban spaces are affected by the issues of gender and sexuality. She elucidated how structures of gender and sexual differences are reproduced by urban spatial arrangements. Therefore, boundaries of individual bodies cannot shape gender and sexuality, but these are shaped by space. Hence, she addressed the problem of gender and sexuality not as a function of a sort of individual body visible in the street but as a function of urban physical and social environments. She viewed street as sexed and gendered. She attempted to explore how women are represented in the modern city. Also, she focused on how the geography of violence and fear constrains women's spatial practices. Thus, she pointed out the gendered use of urban space. Tonkiss (2005) purported that women's presence in urban space is linked with interaction between freedom and danger. The cities are offering young age group of women newer career and freer life in which the women are entering into huge numbers. These women are thereby getting social and spatial liberties, political visibility, and the pleasures of anonymity. Individual women have thus dislodged the dominant order of social space and produced spaces of movements for themselves. Therefore, the city has become the space of freedom for women.

Simultaneously, the presence of women in urban space is also a signification of disorder and danger. The city has become a site of danger for women's fear of male violence regarded as a fear of space. But this real scene of urban space goes unseen that is critical to both freedom and safety for women. Because the gendered subjects that come into view in the street not only handle the physical and social space but also the symbolic spaces- gendered roles and practices, location and conduct of gendered bodies. The gendering of space lies evidently in 
this geography of danger. Geography of danger denotes city as a site of danger that restricts women's full access to and use of urban spaces and perpetuates women's fear of male violence that is unravelled as a fear of space. Geography of gender is simply the margins of freedom and maps of danger that constitutes in the city. Therefore, it can be inferred that geography of gender is the geography of danger in urban space. More specifically, it means marginalizing women when they become visible in public space in the city by jeopardizing women's use of and fear of space. Women's perception of safety and danger is also structured by the physical environment of urban space. Degree of visibility or transparency, openness or easiness of access or way out, better streetlight, employ of closedcircuit television (CCTV) make women feel safer in the urban space.

She postulated that feeling of fear is gendered in the sense that women feel mostly vulnerable to male violence and it is mostly because of sex-related violence. Thus, women's common fear of being mistreated by violence is predominantly underscored by the fear of rape and sexual assault. Again, women's perception of danger and safety is also spatialized that relies on the unstable geography. Geography is unstable in two senses- in the sense that various groups of people occupy urban space and, in the sense, that the ways through which space change over time. Spatialization of danger and safety denotes that particular spaces are dangerous for women. Simultaneously, it means that particular times are dangerous for particular spaces for women because of the uneven distribution of male violence over time and space. Tonkiss (2005) highlighted that space is perceived as dangerous by women because of the unregulated behaviour of men at particular times. These unregulated behaviours of men can take place both in open spaces (parks, towpaths, wasteland) and closed spaces (subways, alleys, laneways, multistorey car parks, train carriages). She exemplified that a railway station or park is fully safe at mid-day but becomes fully unsafe at mid night. Tonkiss (2005, p. 104) says,

The charged nature of space for many women, and the fraught nature of the female body in space are evident in the advice commonly offered to women if they should find themselves on a deserted street after dark: the notion that you should walk in the middle of the road and not on the pavement literally puts women out of place in ordinary public spaces. It might be good advice, but it underlines the way that having a female body can be a spatial liability, and how certain spaces in the city are experienced as a kind of conflict zone. 
Women adopt spatial strategies to avoid danger and remain safe. Women's defensive use of space means to avoid certain places at certain times, use private transport, avoid going out alone at night or seek protection from a man within the heterosexual couples. The strategies vary with respect to race, age, income, status, and lifestyle of women. Women are taught how to use street and where to tread, to observe who are staring at or gazing at, what to do if something unpleasant or irritating situation takes place. Women are advised to avoid pavements and to use middle of the road while walking in the street. Therefore, perception of fear and danger in urban space affects women's use of this space (Tonkiss, 2005).

\section{Findings and Discussion}

This section will discuss how the respondents have defined the new public space of Dhaka from their perspectives and everyday experiences. Importantly, findings have revealed how and why the new space of the city has made it possible for large number of women to come out of their domestic place and to find their livelihood options in different shopping malls, beauty parlours and fashion houses. It will also be discussed how their perception and experiences of harassment as well as violence by men have restricted their freedom and movement in the public space of the city. Also, their free movement in the city has been severely hampered by their protective strategies to be safe in the city. Furthermore, the study has strengthened its findings by connecting them to the theories and studies of prominent scholars in this area of interest.

\section{The new urban space of Dhaka City}

The mounting number of gorgeous shopping malls, innovative fashion houses and a variety of beauty parlours symbolize modern Dhaka's developmental features that were absent in the city few decades ago. Expansion of these private services and increasing number of working women in these sectors are one of the most remarkable features of new urban space of Dhaka city. Rapid growth of service sector is essentially accompanied by increasing consumerism and the rise of consumer class. The study unearths that 23.55 per cent of the respondents explain the new urban space in terms of growth of private service sector, 12.31 per cent in terms of increasing consumerism and 25.36 per cent in terms of increasing working women. These are the new characteristics of urban space along with the overgrowing urban population and influx of people coming from 
the hinterland of the country. Production of new urban space in Dhaka thereby echoes Harvey's (1989) 'appropriation and production of space' by different subjects (e.g., gender, class, group of people etc.) and objects (streets, markets, open spaces, buildings, land use, activities etc.). Beauty parlours, fashion houses and shopping malls are the leading and emerging service sectors that were not so available in the city few years ago and they are growing so fast in the city that everyone can find them nearby and can avail their services. A salesgirl of a shopping mall, Fahima, explained the availability and accessibility of parlour and mall exclusively:

You can find many shops like my one. The city is full of shops, malls, and parlours. Parlour is situated at every corner of subway. Concentration of ten to fifteen shops makes a shopping mall anywhere.

Service centres, departmental stores etc. are also emerging new service sectors in the city. About 38 per cent of the respondents point out shopping malls, nearly 74 per cent beauty parlour, 45 per cent fashion house as the flourishing service sectors in the city of Dhaka. All these features together have made the city 'The centre of civilization'. Harvey (2009) described this urban redesign as the commodification of city and city life.

\section{Putting Female Body in New Urban Space of Dhaka}

Nowadays both men and women are found working in the city of Dhaka. But the proportion of the engagement of men in new service economy is not greater than that of women in the city of Dhaka. Around 87 per cent respondents commented that women were more recruited than men in new private services and 4 per cent replied the vice versa. Nearly, 13 per cent respondents argued that both men and women were being recruited in the new service sectors in the city. But it is also unfortunate that the female service workers who are now visible in a large number in public space of the city are experiencing harassment and perceiving fear of being harassed by male violence. There is hardly any woman who has not experienced some sort of harassment in the public space. The study revealed that about 87 per cent of female workers reported their experience of harassment in public space and nearly 13 per cent did not report their experience of harassment in public space. These experienced interactions which take place in and around the space have been typified by Lefebvre (1991) as material spatial practices. 
Table 1: Types of open and closed space where women feel unsafe

\begin{tabular}{|l|c|l|c|}
\hline \multicolumn{2}{|c|}{ Fairly unsafe open space } & \multicolumn{2}{c|}{ Fairly unsafe closed space } \\
\hline $\begin{array}{l}\text { Types of open } \\
\text { space }\end{array}$ & $\begin{array}{c}\text { Women feeling } \\
\text { unsafe (per cent) }\end{array}$ & Types of closed space & $\begin{array}{c}\text { Women feeling } \\
\text { unsafe (per cent) }\end{array}$ \\
Streets & 21.08 & $\begin{array}{l}\text { Subways/underground } \\
\text { ways }\end{array}$ & 27.71 \\
Parks & 4.22 & Alleyways & 16.87 \\
Lakeside & 2.41 & Public bus & 20.48 \\
Bus stops & 4.22 & Shops & 3.01 \\
Total & 31.93 & Total & 68.07 \\
\hline \multicolumn{2}{|c|}{ Total $=(31.93+68.07=100)$} \\
\hline
\end{tabular}

Table 1 shows that the closed public space is more unsafe than open space as perceived by most of the women. Around 64 per cent women feel unsafe in closed space such as subways, underground ways, alleyways, public bus, shops etc. and closely, 26 per cent in open space such as street, parks, and lakeside. Almost 10 per cent women perceive both closed and open space unsafe for them. Table-1 confirms that about 45 per cent respondents perceive subways and alleyways and nearly, 20 per cent perceive public bus risky for them due to male violence. Further, roughly 21 per cent female service workers feel unsafe whenever they remain in the streets. Women's perception of danger and safety by their everyday common-sense has distinctively reproduced Lefebvre's 'representation of space' (Lefebvre, 1991). Thus, the new urban space of Dhaka puts female body in space and submits it to the authority of capitalism and at the same time male violence. Therefore, the meaning of new urban space revealed in the study strongly fits with Harvey's (1989) 'Dimensions of spatial practices' (Harvey, 1989).

As women are availing more recruitment opportunities in these sectors, they are getting more empowered in the city life. The role of new service sectors is contributing to weakening or breaking down patriarchy. The study demonstrated that about 96 per cent of the respondents viewed women as more empowered through their employment in the modern Dhaka. Traditional masculinity is thereby on the verge of extinction in the face of women's increasing empowerment of women. According to the perception of almost 83 per cent of the respondents, patriarchy is weakening and approximately 13 per cent opined that patriarchy is breaking down. So, men have invented a new way to uphold 
their masculinity against the opposite sex. Whereas the traditional masculinity of men is used to be forced against wife inside the home, modern masculinity is forced against women in public space of the city. Therefore, previously enforcement of masculinity against women used to take the form of domestic violence while enforcement of modern masculinity has taken the form of harassment of women in urban public space.

Peoples (2008) argued that high unemployment rate among men generates disappointment and difficulties to preserve conditions of patriarchal structures and thereby they are holding their masculinity by harassing women in public space. In this study around 49 per respondents insisted that men are now showing down patriarchy in public by harassing women whereas nearly 32 per cent claimed that men are accepting weakening patriarchy. Merely 10 per cent of the respondents stated that men are still upholding patriarchy within family to reinforce traditional masculinity. With women's increasing visibility outside home, violence against women has also come outside home and has threatened women's prestige in public space and thereby women's right to the city. From this point of view, Tonkiss (2005) posited that women's visibility in public space relates to the interaction between freedom and danger because women's social and spatial liberties are simultaneously creating troublesome effects on society by disturbing social and moral order. The study reproduced Tonkiss's (2005) theoretical standpoint by confirming that Dhaka is creating space of movement for younger generation women which has displaced dominant order of the space. The city appears as a space of freedom for women. The new service sectors, more specifically, beauty parlours, fashion houses and shopping malls are the up-andcoming livelihood options for young and less educated women in the city of Dhaka. Of the female beauticians and receptionists studied, approximately 87 per cent are within 30 years of age. Therefore, these are the sectors where young women work for their survival in the city. These are also the sectors which provide employment opportunities mostly for the women with educational background from class six to HSC. Also, the girls who have no schooling or have had their academic qualification up to class five are recruited in beauty parlour, fashion house and shopping malls. Amongst the respondents almost 30 per cent from the educational level of class 6-10, about 29 per cent from SSC and roughly 26 per cent from HSC. Nearly 6 per cent is from 'no schooling' to 'up to class five' background. Further, all the respondents (13per cent) from the indigenous background work in different beauty parlours. Therefore, beauty parlour is the 
only new service sector which offers the means of subsistence for the indigenous girls and women and thereby opens the carrier window for the disadvantaged section living in the city of Dhaka.

Surprisingly, with the growth of new service sectors i.e., beauty parlour, fashion house and shopping mall, more women have been visible in workplace and public place that was impossible for women a few decades ago. About 98 per cent respondents opined that it was impossible for women to go out of their home and engage in outside works few decades ago. And it is the credit of different beauty parlours, fashion houses and shopping malls to bring out huge number of women out of their four walls. For Tonkiss (2005), it is the success of the great city that has made possible women's visible presence in urban space by giving them new jobs and free life.

\section{Experience and Perception of Danger by Women in New Service Economy}

The new urban space of Dhaka has been produced through an interaction between women's increasing accessibility to public places and their use of different modes of transport to manage the distanciation between living place and working place. Again, the study explored an interrelation between transportation practices and harassments of women. All these interactions have replicated Harvey's (1989) 'Production of space'. Female service workers in beauty parlours, fashion houses and shopping malls are to use streets, public transport, bus stops daily to earn their bread in the city and some use markets out of necessity. As they are to work for longer periods even sometimes covering the unsociable working hours throughout the week, they get hardly any leisure time to enjoy other urban public space for recreational purposes even in the weekly holiday. However, parks and lakeside are also used by a very few women occasionally. Peters (2001) shows that walking and public transport are major modes of transportation for both men and women in the city of Dhaka. The present study also unearths that firstly, public transport and secondly, walking mode are major means of the female service workers to commute between their workplace and living place. The research indicates that the proportion of user of public transport is around 47 per cent and walking mode is about 38 per cent for communicating between living and working place. These findings replicate the study of Peter (2001). Some women use rickshaw to avoid harassment by men in the street. Battery-driven vehicle is a special local mode of transport used by a few salesgirls to come from and go back to their living places. When the distance between the workplace and 
living place is greater, public transport is the most available and affordable mode of transport to travel. So, the female service workers are to use this mode for travel daily in the city. When the living place is situated near the workplace, women use walking mode regularly to cover the distance. Some women used to walk from their neighbourhood to the bus stops daily. Again, some women use rickshaw as it is less expensive. Again, some use rickshaw as they have avoided public bus for the fear of violence. Women (33.3 per cent) reported that they use battery driven vehicle that is less expensive but not that much women friendly.

The city of Dhaka has become a site of danger for women because of male violence or fear of violence who are to come out of their home and use public places. This situation tunes with Tonkiss's (2005) 'Geography of danger'. Nonsexual and sexual physical violence are experienced in a greater proportion by female service workers travelling by public transport than those using walking mode. In Dhaka city public transport system is unfortunately over-ridden with various problems such as over-crowd, inaccessibility to crowded bus for aged, handicapped and women, waiting long period of time at bus stop, harassing situations for female passengers (Rahman, 2012). On the contrary, verbal harassment is experienced more by women using walking mode than those using public transport.

Table 2: Use of transport by women and experience of harassment in public space of Dhaka

\begin{tabular}{|l|c|c|c|c|c|c|}
\hline \multirow{2}{*}{$\begin{array}{l}\text { Types of public } \\
\text { place harassment } \\
\text { experienced }\end{array}$} & \multicolumn{5}{|c|}{ Mode of transportation used by female service workers daily } \\
\cline { 2 - 7 } & $\begin{array}{c}\text { Public } \\
\text { transport }\end{array}$ & Walking & Rickshaw & $\begin{array}{c}\text { Battery driven } \\
\text { vehicle }\end{array}$ & $\begin{array}{c}\text { Not } \\
\text { applicable }\end{array}$ & Total \\
\hline Nonsexual physical & 28.87 & 19.01 & 4.93 & 2.11 & 45.77 & 100 \\
\hline Sexual physical & 35.71 & 17.86 & 4.29 & 2.14 & 40 & 100 \\
\hline Verbal & 15.59 & 53.23 & 6.45 & 3.23 & 21.51 & 100 \\
\hline
\end{tabular}

Table 2 draws attention on the fact that of non-sexual and sexual physical harassment, around 65 per cent is experienced by women using public transport whereas of verbal harassment about 53 per cent is experienced by women using walking mode. For, Scott (2003) exposed that women feel fear when they use public transport. Lefebvre (1991) puts forward that subjugation takes place in the street and thereby, represses movement. Goheen (1998) reinforced that new public space such as streets represent variety of activities of dangerous behaviour. 
The supposition of Pain (1997) has been reproduced in the present study that women's susceptibility in public space is dependent on women's mode of transport. Approximately, 19 per cent claims that mode of transportation is responsible for making women vulnerable to harassment in public space. Nearly, 13 per cent respondents comment that living place and more specifically greater distance of living place from working place accounts for women's harassment in public space of the city. Again, women's harassment in public places is dependent on their age, occupation, lifestyle, ethnicity, location of living place. The study unearths that 17.68 per cent respondents viewed women's age and 8.84 per cent ethnicity responsible for making them harassed in public space. Yet again, 15.47 per cent commented that occupation is responsible for women's harassment in public space of Dhaka. Occupation in new service sectors make women vulnerable to teasing by men in the city public space, particularly in the public transport and street or subway at some unsociable times. A young beautician commented:

I become afraid when it is night. At the month of Ramadan (the month of starvation practiced by Muslim community), it became one, two, three, four at night. We have not still faced any problem. However, we always feel scared of being harassed in public place.

Again for 18.23 per cent respondents, life-style account for women's harassment as revealed by the study. Another 6.63 per cent of the respondents argued that men harass women in public places without any reason as it has become their habit. Therefore, gendered subjects in space have something to do with gendered roles and practices, location and conduct of gendered bodies (Tonkiss, 2005).

Most of the female service workers surveyed for the study (58.5 per cent) have absolute and moderate freedom in their workplace. But 9.2 per cent is somewhat free. And 41.5 per cent is more or less restrained in their workplace by disturbance from male colleagues or outsiders. They are harassed by their male colleges who continuously disturb them by offering them marriage proposal or proposal for making love relationship, asking for their mobile number, and following up them towards their home and even sometimes by blackmailing them. Sometimes young boys disturb the beautician in their workplace by tagging papers with indecent language and hanging them on the wall or the door of the parlour or by giving phone calls frequently and asking for different girls. Even when the beauticians leave their parlour, they are underestimated and teased by 
men at the way out of the parlour. About 60 percent of women are to experience teasing and around 29 per cent of them feel fear of being teased while using the public space.

Rabeya Mahfuz, manager of a fashion house explained women's freedom in public place, "Women have no freedom in public place. Fifty years will be required to ensure women's freedom".

Some of the female service workers have got accustomed to harassing incidents as they experience these awkward situations frequently. Only, very limited number of women can enjoy public space of Dhaka city fairly. Nearly 9 per cent has got habituated with the harassing incidents in public space. Only 12 per cent enjoy freedom and movement moderately while remaining in public place of the city. Fear of harassment thus makes women unrelaxed in public space (Davidson, Butchko, Robbins, Sherd, \& Gervais, 2016). Majorities of the respondents (around 68 per cent) perceive that particular places become dangerous for women at night-time. Almost 23 percent women perceive morning time as unsafe for women when they use certain public spaces to reach their workplace. Nearly 15 percent respondents think that almost all the times public spaces are unsafe for women and 10 per cent claim afternoon and evening as fearful for women. These imaginary settings have been characterized by Harvey (1989) as 'Psychological inventions'. Again, he purported that space is occupied by particular persons, classes, or social groups of people (Harvey, 1989). The survey reveals that unemployed deviant youth, middle aged men, rickshaw puller, drunkards, vagabond people always harass or attempt to harass women when they come out of their home in the morning for their work, ride by public transport, walk through subways or alleyways or at the night-time when the women are on their way towards home. This situation strongly supports Tonkiss's (2005) 'Unstable geography' since space changes over time and particular groups of people make space dangerous for women at particular times.

The concept of unstable geography has become a reality in the story of Nasima:

Interviewer : In what types of places and when you are being harassed frequently?

Nasima : On my way towards home after dark. Those who know that I pass by the subway daily around $8.00 \mathrm{pm}$ to $9.00 \mathrm{pm}$, await me in the same place at the same time to disturb me. 
Interview : What do they generally do?

Nasima : They generally used to make bad remarks when they find me at night such as, 'look, look, the second graded good is coming'.

Almost 22 per cent respondents of different age groups mentioned their fear of pushing bodies by men while using public space. Again, about 22 per cent respondents are fearful of deliberately tapping by men and 14 percent of winking and making provocative expression by men in public places. Only around 6 per cent of the respondents are afraid of different harassing incidents targeting towards them such as throwing papers, spitting, kidnapping, throwing acid etc. Just about 36 per cent respondents overlooks or does not fear of non-sexual physical violence. Mostly the young service girls are fearful of experiencing nonsexual physical harassment in public space. Also, about 39 per cent respondents of different age groups surveyed reported their fear of being touched the most in public space, 19 per cent reported fear of being raped, 13 per cent reported fear of caressing their private areas by men, 12 per cent fear of being grabbed in public places. Approximately 17 per cent respondents did not mention their fear of facing sexual physical violence. The fear of experiencing bad or sexually explicit comments is felt by most of the female service workers (47.59 per cent) surveyed.

A young receptionist of a shop expressed her fear when she remains in public places, "The matter of losing prestige in public space is the greatest issue for a woman. Nothing is to be done if anyone says something bad about a girl or woman".

In this study, 10.34 per cent mentioned their fear of experiencing hissing and kissing sounds in public space; 9.66 per cent is fearful of experiencing leering while remaining in public places of Dhaka and 3.45 per cent of experiencing of whistling. Therefore, fear and danger are always gendered and spatialized as proposed by Tonkiss (2005). The respondents also argued that streets, public transports, markets, bus stops are becoming unsafe for women because of increasing crowd, decreasing day-time crowd, lack of surveillance, poor lighting, and shortage of transport. Lefebvre suggested that busy women remain safe in busy streets while they become unsafe for criminal violence in vanishing streets. In this study, 28.43 per cent women confirmed Lefebvre's (1991) proposition that decreasing daytime crowd accounts for unsafe public places. But roughly 27 per cent women experience harassment in crowd. Again, around 20 per cent 
respondents insisted that it is lack of surveillance that contributes to make the public places dangerous for women. Besides, 20.81 per cent shared that women become harassed in public places for poor lighting in the city.

\section{Protective Use of Space}

To avoid danger and stay safe in the public space of Dhaka city, almost all the female service workers adopt protective strategies. Among the protective strategies avoiding walking alone at night (about 28 per cent) and avoiding unsafe and unknown places (about 27 per cent) are adopted by most of the women. A significant number of women (nearly 19 per cent) also avoid travelling alone. Some female service workers (approximately 6 per cent) have avoided public transport to remain safe while using the public place of Dhaka city. Many of the women (nearly 10 per cent) avoid crowd and waiting at bus stops after dark to keep themselves aloof from unavoidable harassment in the public space of the city. These are the spatial codes as proposed by Lefebvre (1991) which constrain women's activities in public space, discourage and disallow their gesture, way, and distance to be covered. The adoption of protective strategies by female service workers for their perception of fear and danger reinforces Tonkiss' (2005) 'protective use of space' (Tonkiss, 2005). Women's perception of danger is socially built up which affects women's use of urban space. Thus, space has become a social construction as space is itself the product of social practices and social practices are reproduced in space (Hille, 1999). More specifically, urban space of Dhaka is produced by parental advices, discussion among friends, colleges as revealed by the study. Social practices such as to avoid dark, unsafe place, moving alone, wearing modern dress etc. are produced in the same space. In the study 14.38 per cent respondents mentioned that their family suggests them to move decently or modestly. Further, 13.01 per cent respondents' family and relatives advised girls and women not to protest harassment if they face in public places. Akhter agreed that women do not disclose any incident of being harassed for the fear of further harassment (Akhter, 2013). Also, 10.27 per cent of the female service workers' family gives them order to return home before night-time and another 10. 27 per cent of the respondents' family advised them to avoid ultra-modern dress. The survey also uncovers that 7.53 per cent respondents' family and colleges forbid female service workers to use subways, alleyway, and certain dangerous places. Another 7.53 per cent respondents is socialized to avoid strangers and talk to them and again 7.53 per cent is socialized not to move alone. 
It also reveals that 14.38 per cent female service workers get suggestions to avoid male friends or boyfriends, to avoid going unknown place alone and to make the teasers understand softly not to disturb them. Again 11.64 per cent respondents are made anxious about experiencing of harassment in public space by media news and reports. Only 3.42 per cent female workers did not mention any suggestion or awareness given by their family, friends, and colleague. This corresponds to argument of Doran and Burgess (2012) that behavioural adaptation is affected by fear of crime.

Freedom and movement of most of the female service workers in public place of the city is restricted by their adoption of different protective behaviours in order to avoid harassment by male violence while remaining outside their own home. Implementation of protective strategies mostly hinders women's free movement in the public places. The present research reveals that 51.15 per cent female service workers who adopt protective strategies to avoid danger cannot move freely in public space. It also interrupts to enjoy their jobs or engagement in the new service economy. Following protective tactics interrupt 21.84 per cent women to do and enjoy their jobs freely. It also creates fear of male violence when they remain in the public space alone. The freedom and movement of 9.77 per cent respondents who adopt protective strategies is hampered in public space as they are always fearful of male violence while remaining alone in the public places. Following different protective strategies by women in the service sectors also makes it compulsory for them to be accompanied by others for their own protection and thereby impedes their freer movement in the public places of Dhaka. Some women also cannot maintain modern lifestyle for adopting protective tactics to remain safe in public place of the city. For 4.6 per cent respondents adopting protective strategies creates obstacle for them to enjoy modern lifestyle. Shamma (2017) represented that perceived vulnerability of being attacked restricts women's freedom of movement in cities and towns.

\section{Conclusion}

The public space of Dhaka city has been reshuffled with a purely economic concern. This economic concern has produced new private services and consumer culture in the city of Dhaka. The new private service sectors, particularly shopping malls, fashion houses and beauty parlours are providing young, less educated, and indigenous girls with both full time and part time jobs and thereby 
empowering women with their increasing visibility in the public space of the city. Thus, the city has become a space of freedom and movement for women. With this role of the new service economy of the city it has also put female body in space and has submitted it to the authority of men and male violence. This is exactly the fact of putting body in space with the capitalist interests. The working women in the new service sectors are to come out of their home and go for their workplace daily. They are to use different mode of transportation to commute between workplace and living place. Most of the women use public transport and walking mode determined by the distance of their workplace and residence. Public transport, streets and subways are the most convenient places for men to harass women. These women are to leave their workplace at night daily and at late night occasionally. At that time, these public places become more unsafe for these women. They also use bus stops, markets, parks daily and sometimes in their weekly holiday. But these places are not also safe for women due to harassment by men. They have also developed a psychology of fear of public space of the city by their socialization as girls. They perceive particular places as dangerous at particular times. Their fear and experience of danger is also determined by their age, ethnicity, and lifestyle. The urban social and physical environment also intensifies women's possibility of being harassed in public space of Dhaka city. Their protective use of the public space impedes their free movement in the city. Women's presence and movement in the public space, their perception and experience of harassment and protective use of space together constitute their spatial practices of the city. Thus, the new urban space of Dhaka city revealed by the study reiterates Harvey's (2009) appropriation and domination of space. Further, women's use of urban space replicates Lefebvre's (1991) production of space and spatial code and Tokiss's (2005) geography of gender in the city space.

\section{References}

ActionAid. (2014). Safe Cities for Women: From reality to rights. Retrieved from https://actionaid,ie/wp-content/uploads/2016/10/Safe-Cities-for-Women-from-Realities-toRights-1.pdf (Accessed on November 20, 2020).

Akhter, Z (2013). Eve teasing, tears of the girls: Bangladesh Open University towards women empowerment. International Women Online Journal of Distance education, 2(4), 1-3.

Davidson, M. M., Butchko, M. S., \& Robbins, K. (2016). The mediating role of perceived safety on street harassment and anxiety. Psychology of Violence, 6(3), 553.

Friedmann, J., \& Wolff, G. (1982) World city formation: an agenda for research and action. International Journal of Urban and Regional Research, 6(3), 46-54. 
Goheen, P. G. (1998). Public space and the geography of the modern city. Progress in Human Geography, 22(4), 479-496.

Harvey, D. (1989). The condition of postmodernity: An Enquiry into the Origins of Cultural Change. Cambridge MA: Blackwell.

Harvey, D. (2009). Social Justice and the city. Athens: University of Georgia Press.

Hille, K. (1999). 'Gendered Exclusions': women's fear of violence and changing relations to space. Geografiska Annaler: Series B, Human Geography, 81(2), 111-124.

Khan, S. (2013). Women, safety and the city of Mumbai. Economic and Political Weekly, 12-13.

Koch, R., \& Latham, A. (2013). On the hard work of domesticating a public space. Urban Studies, 50(1), 6-21.

Lefebvre, H., \& Nicholson-Smith, D. (1991). The production of space. Oxford: Blackwell Publishing.

Ortiz, A., Garcia-Ramon, M. D., \& Prats, M. (2004). Women's use of public space and sense of place in the Raval (Barcelona). GeoJournal, 61(3), 219-227.

Pain, R. H. (1997). Social geographies of women's fear of crime. Transactions of the Institute of British geographers, 22(2), 231-244.

Phadke, S. (2013). Unfriendly bodies, hostile cities: Reflections on loitering and gendered public space. Economic and Political Weekly, 48(39), 50-59.

Peoples, F. M. (2008). Street harassment in Cairo: a symptom of disintegrating social structures. African Anthropologist, 15(1\&2), 1-20.

Peters, D. (2001). Gender and transport in less developed countries: A background paper in preparation for CSD-9, Background Paper for the Expert workshop "Gender Perspectives for earth Summit 2002: Energy, Transport, Information for Decision-making” Berlin, Germany, 10-12, Paper commissioned by UNED Forum.

Rahbari, L., \& Sharepour, M. (2015). Gender and Realisation of Women's Right to the City in Tehran. Asian Journal of Social Science, 43(3), 227-248.

Rahman, M., \& Kasphia, S. (2012). Bus services in Dhaka city-users' experiences and opinions. Journal of Bangladesh institute of Planners, 2075(4), 9363.

Reichenbach, A. (2015). Gazes that Matter: Young Emirati Women's Spatial Practices in Dubai. Urban Anthropology Studies of Cultural Systems and World Economic Development, 44(1/2), 113-195.

Scott, H. (2003). Stranger Danger: Explaining Women's Fear of Crime. Western Criminology Review, 4(3), 203-214.

Shamma, W. T. (2017). Women's Mobility, Mental Mapping and Margin of Freedom in Urban Public Space: Case of Women Working in New Service Sectors of Dhaka City. Journal of the Asiatic Society of Bangladesh (Hum.), 62(2), 233-49.

Soenen, Ruth. (2007). Everyday Urban public space: Turkish Immigrant Women's Perspective. Journal of Housing and the Built Environment, 22(4), 411-413.

Thorbek, S. (1988), Women and Urbanization. Acta Sociologica, 31(4), 283-301

Tonkiss, F. (2005). Space, the City and Social Theory: Social Relations and Urban Forms. United Kingdom: Polity.

Valentine, G. (1989). The Geography of women's fear. AREA, 21(4), 385-390.

Walsh, S. M. (2015). Safety Spheres: Danger Mapping and Spatial Justice. Race, Gender \& Class, 22(1 \& 2), 122-142. 